\title{
FORMULASI HUKUM PIDANA TERHADAP RUMUSAN TINDAK PIDANA PERZINAAN DALAM PEMBAHARUAN HUKUM DI INDONESIA
}

\author{
Ihda Shofiyatun Nisa' \\ Kantor Advokat Kota Malang \\ Email : ihdashofiya95@gmail.com
}

\begin{abstract}
Abstrak
Penelitian tentang formulasi hukum pidana terhadap rumusan tindak pidana perzinaan dalam pembaharuan hukum di Indonesia bertujuan untuk mengetahui dan menganalisis tentang kebijakan formulasi hukum pidana dalam merumuskan delik perzinaan dimasa sekarang dan yang akan datang terhadap pembaharuan hukum di Indonesia. Hasil penelitian dan analisis data dalam penelitian ini menyatakan bahwa: pertama, pada dasarnya saat ini sudah terdapat kebijakan hukum pidana yang berkaitan dengan rumusan perzinaan. Yaitu, KUHP Pasal 284 tentang perzinaan, Yurisprudensi MA Nomor 93/K/Kr/1976 yang menyatakan bahwa "pengadilan negeri berwenang untuk memeriksa dan memutus perbuatan yang menurut hukum adat dianggap sebagai perbuatan pidana yang mempunyai bandingan dengan KUHP”. Keputusan MA No 349/K/Kr/1980 tanggal 26 Desember 1980 mengenai perkara Pasal 284 (1) Ia KUHP. Namun beberapa kebijakan ini belum berlaku secara maksimal, karena masih mengandung beberapa kekurangan antara lain dalam perumusan delik Pada Pasal 284 yang mengkategorikan zina sebagai delik aduan absolut. Kemudian dalam sistem perumusan sanksi yang tidak tepat dan jumlah sanksi pidana penjara serta denda masih relatif kecil. Kedua, adanya kelemahan dalam kebijakan saat ini maka perlu adanya kebijakan formulasi hukum pidana dalam upaya perumusan delik perzinaan. Kebijakan hukum yang akan datang berkaitan dengan perumusan delik perzinaan adalah konsep RUU KUHP Versi September 2019. Didalam telah merumuskan perzinaan dalam segala bentuknya, baik adultary (muhson) ataupun fornication (ghairu muhson). Selain itu, juga terdapat rumusan mengenai kumpul kebo serta incest.
\end{abstract}

Kata kunci: formulasi, hukum pidana, perzinaan.

\begin{abstract}
Research on the formulation of criminal law on the formulation of criminal acts of adultery in legal reform in Indonesia aims to find out and analyze the policy on the formulation of criminal law in formulating offenses for adultery in the present and future of legal reform in Indonesia. The results of research and data analysis in this study states that: first, basically there is now a criminal law policy relating to the formulation of adultery. Namely, KUHP Article 284 regarding adultery, MA Jurisprudence Number 93 / K / Kr / 1976 which states that "the district court has the authority to examine and decide upon acts which according to customary law are considered as criminal offenses which have a comparison with the Criminal Code". MA Decree No. 349 / K / Kr / 1980 dated December 26, 1980
\end{abstract}




\section{$\mathcal{H}$ urnal Negara dan $\mathcal{X}$ eadilan \\ p-ISSN 2302-7010 e-ISSN 2721-9801}

regarding the case of Article 284 (1) He is the Criminal Code. However, some of these policies have not yet been implemented to the fullest, because they still contain some shortcomings, including in the formulation of offense Article 284 which categorizes adultery as an offense of absolute complaint. Then in the formulation system of improper sanctions and the number of sanctions imprisonment and fines are still relatively small. Second, there are weaknesses in the current policy so it is necessary to formulate a criminal law policy in the formulation of an offense for adultery. The next legal policy relating to the formulation of the offense for adultery is the concept of the Criminal Code Bill for the September 2019 version. It has formulated adultery in all its forms, both adultary (muhson) or fornication (ghairu muhson). In addition, there are also formulations regarding cohabiting and incest gatherings.

Keywords: formulation, criminal law, adultery

\section{PENDAHULUAN}

Upaya pembaharuan hukum pidana hakhir-akhir ini sedang diperbincangkan halayak umum. Berbagai kalangan telah membahas permasalahan ini yaitu mengenai pembaharuan rumusan kebijakan hukum pidana yang bersumber dari KUHP. KUHP Indonesia merupakan warisan Belanda dan dianggap tidak sesuai dengan Pancasila sebagai dasar ideologi bangsa Indonesia. saat ini KUHP yang berkembang di Indonesia tidak lebih dari produk peninggalan penjajahan Belanda, maka dari itu nilai-nilai yang terkandung didalam KUHP tidak sesuai dengan karakteristik Bangsa Indonesia.

Tiga latar belakang yang menurut Barda Nawawi Arief sangat penting dalam pembaharuan hukum di Indonesia, yaitu aspek sosio politik, sosio filosofik, dan sosio kultural. Alasan politik, cita-cita bangsa yang telah merdeka adalah memiliki produk hukum sendiri atau memiliki KUHP baru yang sesuai dengan bangsa Indonesia. kedua alasan sosiologis, bahwa aturan didalam hukum pidana merupakan cerminan dari pandangan politik suatu bangsa dimana hukum itu dibuat dan berkembang. Disini nilai-nilai kebudayaan itu mendapat tempat dalam mengatur hukum pidana. Tolak ukur perbuatan jahat itu dapat diukur dari mayarakat dalam menilai suatu perbuatan, baik atau buruk, benar atau tidak benar apa yang bermanfaat dan sebaliknya.

Peranan hukum pidana dalam pembentukan aturan dan ketertiban sosial sering kali menuai kontroversi. Salah satunya dalam upaya perumusan mengenai delik perzinaan yang diatur dalam Pasal 284 KUHP. Hal ini menuai perdebatan yang sangat panjang dan sengit. Rumusan KUHP tentang perzinaan dalam Pasal 284 ini merupakan cerminan nilai-nilai yang berkembang dan dianut oleh masyarakat

Barat. Jadi bukan merupakan nilai-nilai yang berkembang dan dianut oleh masyarat Indonesia. Maka dari itu, didalam penelitian ini penulis ingin sedikit menguraiakan bagaimana subtansi hukum yang berkaitan dengan perzinaan, baik yang hukum positif sekarang berlaku (ius contitutum) maupun hukum yang di cita-citakan (ius contituendum).

\section{METODE PENELITIAN}

Jenis penelitian yang digunakan dalam penelitian ini adalah yuridis normatif. Adapun pendekatan yang digunakan dalam penelitian ini ada tiga, yaitu: 


\section{Jurnal Negara dan $\mathcal{X}$ eadilan \\ p-ISSN 2302-7010 e-ISSN 2721-9801}

pendekatan konsep hukum (conceptual approch), pendekatan perundangundangan (statute approch), dan pendekatan kasus-kasus hukum (case law approch). Didalam menganalalisis, menggunakan metode deskriptif analisis yaitu data yang dikumpulkan diolah secara kualitatif, yang terdiri dari bahan hukum primer, bahan hukum sekunder, dan bahan hukum tersier. Semua data kami pilahpilah data yang relevan maupun yang tidak relevan dalam penelitian.

\section{PEMBAHASAN}

\section{Statistik Delik Perzinaan}

Zina adalah perbuatan keji seperti halnya homoseks, dan hubungan seks yang menyimpang telah tersebar luas ditengah-tengah masyarakat. Berdasarkan data kependudukan dan keluarga berencana nasional (BKKBN) memperkirakan angka aborsi pada anak usia remaja di daerah perkotaan meningkat secara segnifikan. Dilihat dari data survey demografi dan kesehatan Indonesia (SDKI), data tahun 2008 rata-rata nasional angka kematian ibu melahirkan (AKI) mencapai 228 peer 100 ribu kelahiran hidup. Sementara itu, laporan pada tahun 2013 dari Australia consortium for in country Indonesian studies menunjukan hasil penelitian di 10 kota besar dan 6 kabupaten di Indonesia terjadi 43 pesen aborsi per 100 kelahiran hidup. Aborsi tersebut dilakukan oleh perempuan diperkotaan besar sebanyak $78 \%$ dan perempuan dipedesaan sebanyak 40\%. Fasli mengatakan bahwa, perempuan yang melaukan aborsi didaerah perkotaan di Indonesia umumnya berusia 15 - 19 tahun. Abarsi dilakukan karena kecelakaan atau kehamilan diluar pernikahan. Dapat pula dilohat dalam SDKI tentang laporan pernikahan, bahwa usia remaja semakin meningkat terutama didaerah perkotaan, yaitu mencapai $48 \%$ dari total pernikahan nasional. ${ }^{1}$

Selain itu, penulis juga mengkaji dari kenapa seseorang itu melakukan perzinaan. Didalam uraian ini jika zina terjadi pada pasangan suami istri yang telah terikat pada perkawinan yang sah maka bisa kita identikkan dengan perselingkuhan. Perselingkuhan ini sangat banyak jenis dan coraknya, mungkin memang sulit untuk mengetahui dengan pasti apa yang menjadi penyebab perselingkuhan. Namun agar kita memiliki gambaran tentang sebab atau motif seseorang melakukan hal tersebut, maka bisa melihat rujukan pustaka sebagai berikut. Dalam uraian ini, seseorang melakukan perselingkuhan itu karena beberapa faktor atau alasan sebab sebagai berikut:

a. Mencari variasi baru dalam pengalaman seksual.

b. Melakukan pembalasan atas ketidaksetiaan pasangan.

c. Menentang norma monogami, menunjukan penolakan terhadap norma mayarakat yang dianggap membatasi kebabasan.

d.Mencari kepuasan emosional yang tidak terpenuhi dalam perkawinan.

e. Hanya untuk memperoleh kesenangan semata.

f. Untuk membuktikan bahwa dirinya itu masih muda dan masih menarik.

g. Memiliki hubungan persahabatan dengan seseorang diluar perkawinan.

\section{${ }^{1}$ Utami Diah Kusumawati, Tercatat Angka Aborsi Meningkat}

di Perkotaan, https://www.cnnindonesia.com/nasional/20141029111311-128642/tercatat-angka-aborsi-meningkat-di-perkotaan, diakses 28/11/2019, pukul 23.31 WIB. 


\section{Hurnal Negara dan $\mathcal{X}$ eadilan \\ p-ISSN 2302-7010 e-ISSN 2721-9801}

h. Suami istri mendorong hubungan gelap tersebut, misalnya suami yang selingkuh mendorong istri untuk melakukan hal yang sama. ${ }^{2}$

Dalam artikel Negeri Darurat Pelacuran dan Seks Bebas ${ }^{3}$, pelacuran di Indonesia itu diibaratkan sebagai penyakit kanker, yaitu merupakan penyakit yang serius dan sudah mencapai stadium gawat. Pada tahun 2008, menurut koalisi nasional penghapusan eksploitasi sesksual komersial anak (ESKAA) sekurangkurangnya tiap tahun ada 150.000 anak Indonesia menjadi korban pelacuran anak dan pornografi. Angka itu meningkat 100 persen lebih dari statistik PBB tahun 1998 yang mencatatt anak Indonesia menjadi korban pelacuran pornografi (kompas.com, 14/10/2008).

Sepanjang tahun 2011 bisnis ini berkembang sangat pesat. Nilai transaksi pelacuran tiap bulan sekitar 5,5 triliun. Angka ini dilihat berdasarkan jumlah PSK yang dikeluarkan beberapa lembaga seperti united nations development programme (UNDP), dinas sosial, dan komisi penanggulangan AIDS di Indonesia sekitar 193.000

- 272.0000 (infobanknews.com 23/08/2012). Banyaknya PSK berati menunjukan banyaknya prima yang suka berzina. Menurut kementrian kesehatan, ada sekitar 6,7 juta laki-laki yang membeli seks pada 2012. Jumlah ini meningkat daripada tahun 2009 (kompas.com, 3/12/2012). Dari seks bebas ini rentan terkena penyakit mematikan, yaitu termasuk HIV/AIDS tapi semua ini tidak difikirkan oleh seseorang yang gemar melakukan seks bebas. Pada Juni 2012 tercatat 3.368 kasus AIDS pada ibu rumah tangga, dan 775 pada balita (kompas.com, 3/12/2012). Kemudian per tanggal 1 Januari - 30 Juni 2012 total kasus HIV/AIDS di Indonesia tercatat 9.883 kasus HIV dan 2.224 kasus AIDS, dari jumlah tersebut 45 persen diantaranya adalah anak muda.

\section{Dampak Negatif Perzinaan}

Zina merupakan perbuatan keji yang banyak menimbulkan kerusakan dimuka bumi, antara lain:

1. Perbuatan zina yang dapat merusak kesakralan dan kesucian lembaga perkawinan. Seorang laki-laki atau perempuan yang melakukan zina, akan menimbulkan stigma negatif terhadap masyarakat sekitar. Sehingga akan menimbulkan ketidak harmonisan, tidak adanya kedamaian, tidak adanya ketenangan dalam kehidupan berumah tangga.

2. Perbuatan zina akan menghancurkan rumah tangga atau keluarga yang bersangkutan. Karena suami atau istri yang melakukan zina, padahal ia tau bahwa ia telah terikat oleh perkawinan berarti ia sengaja menodai pernikahanya dan keluarganya. Karena hal itu maka akan datanglah kehancuran dalam rumah tangganya.

3. Perbuatan zina itu juga dapat mencampur adukkan keturunan, yang mengakibatkan seseorang akan meragukan anaknya sendiri. Apakah anaknya itu adalah keturunan yang sah dari pernikahanya

${ }^{2}$ Kartika Sari, "Forgiveness pada istri sebagai upaya untuk mengembalikan keutuhan rumah tangga akibat perselingkuhan suami”, jurnal psikologi UNDIP Vol.11.no1 April 2012.

3 Musthofa Al Badawi, 2013, Zina mengungkap Ancaman, Fakta, dan Dampak Buruknya, Sukoharjo: Lurik Arafah, hlm 64-67. 


\section{Zurnal Negara dan $\mathcal{X}$ eadilan \\ p-ISSN 2302-7010 e-ISSN 2721-9801}

atau hasil dari perbuatan zina. Kalau terjadi suami menduga istrinya berbuat zina, hal semacam itu dapat menimbulkan keraguraguan dalam kedudukan hukum anak yang bersangkutan. Perihal semacam ini dapat menghambat kelangsungan keturunan dan menghancurkan tatanan masyarakat.

4. Perbuatan zina juga menimbulkan ketidak stabilan dan kegelisaan dikalangan masyarakat. Karena tidak terpeliharanya kesopanan dan kehormatan. Akibat dari perbuatan zina ini banyak menimbulkan tindak pidana terhadap nyawa atau biasa disebut pembunuhan dalam masyarakat.

5. Karena perbuatan zina juga akan menimbulkan penyakit kelamin menular yang sukar untuk disembuhkan. Adapun penyakit menular itu adalah penyakit sifilis, gonore, HIV AIDS dan sejenisnya.

\section{Kebijakan Formulasi Hukum Pidana saat ini dalam upaya Perumusan Tindak Pidana Perzinaan}

Beberapa rumusan kebijakan yang berlaku di Indonesia pada saat ini:

6. Kitab Undang-undang Hukum Pidana (KUHP)

a. Perzinaan bagi orang yang sudah kawin atau salah satunya sudah terikat dengan perkawinan (Adultary)

Menurut Sue Titus Reid adultary ${ }^{4}$ adalah perbuatan seksual yang diyakini sebagai perbuatan immoral yang merupakan yurisdiksi dari banyak hukum pidana. Beberapa yurisdiksi ini membatasi tentang adultary sebagai hubungan seksual yang dilakukan antara dua orang yang apabila salah satunya terikat perkawinan dengan orang lain. Beberapa yurisdiksi lain mengatakan bahwa hanya bagi pasangan yang keduanya sama-sama terikat perkawinan dengan orang lain. Tetapi menurut Reid, ketetntuan adultary pada awalnya hanya diberlakukan bagi seorang perempuan yang terikat perkawinan. Karena biasanya laki-laki menikah yang melakukan hubungan seksual dengan orang lain yang bukan istrinya adalah bukan merupakan kejahatan. ${ }^{5}$ Adultary dalam KUHP terdapat dalam Pasal 284 KUHP yang berbunyi:

(1) Diancam dengan pidana penjara paling lama sembilan bulan:

1. a. Seorang pria yang telah kawin yang melakukan gendak (overspel), padahal diketahui pasal $27 \mathrm{BW}$ berlaku baginya.

b. seorang wanita yang telah kawin yang melakukan gendak, padahal diketahui bahwa pasal 27 BW berlaku baginya;

2. a. Seorang pria yang turut serta melakukan itu, padahal diketahuinya yang tururt bersalah telah kawin;

b.seorang wanita yang telah kawin yang turut serta melakukan perbuatan itu, padahal dikatuhi olehnya bahwa yang turut bersalah telah kawin dan pasal 27 BW berlaku baginya.

(2) tidak dlakukan penuntutan melainkan atas pengaduan suami/istri yang tercemar, dan bilamana bagi mereka berlaku

4 Neng Djubaedah, Perzinaan dalam peraturan perundang-undangan di Indonesia ditinjau dari Hukum Islam, 2010, (Jakarta: Prenada Media Grup), hlm 199.

${ }^{5}$ Ibid, hlm 200. 


\section{Zurnal Negara dan $\mathcal{X}$ eadilan \\ p-ISSN 2302-7010 e-ISSN 2721-9801}

pasal $27 \mathrm{BW}$, dalam tenggang waktu tiga bulan diikuti dengan permintaan bercerai dan pisah meja dan ranjang karena alasan itu juga.

(3) Terdapat pengaduan ini tidak berlaku pasal 72, 73, dan 75.

(4) Pengaduan dapat ditarik kembali selama pemeriksaan dalam sidang pengadilan belum dimulai.

(5) Jika bagi suami istri berlaku pasal $27 \mathrm{BW}$, pengaduan tidak diindahkan selama perkawinan belum diputus karena perceraian atau sebelum putusan yang menyatakan pisah meja dan tempat tidur menjadi tetap. ${ }^{6}$

Jadi dapat ditarik kesimpulan bahwasanya didalam Pasal 284 ini para pakar hukum barat, merumuskan adultary itu hanya sebatas pada perzinaan yang dilakukan oleh kedua pelaku atau salah satunya telah terikat perkawinan. Maka dapat dirumuskan juga bahwa unsur-unsur yang haru dipenuhi dalam pasal ini adalah sebagai berikut:

1) Merusak kesopanan/kesusilaan (persetubuhan)

2) Salah satu atau keduanya telah beristri/bersuami.

3) Salah satu atau keduanya berlaku pasal 27 KUHPerdata.

c. Perzinaan oleh orang yang tidak terikat perkawinan (fornication)

Fornication adalah hubungan seksual yang tidak sah diantara dua orang yang masing-masing tidak terikat perkawinan. Didalam KUHP fornication

tidak diatur secara eksplisit, namun disini diatur fornication dengan anak yang belum berumur 15 tahun atau anak yang belum waktunya untuk dinikahi. Fornication disini diancam dengan hukuman paling lama 9 (sembilan) tahun, sebagaimana Pasal 287 ayat (1) KUHP.

Pasal 287

(1) Barang siapa bersetubuh dengan seorang wanita diluar pernikahan, padahal diketahui atau sepatutnya harus diduga, bahwa umurnya belum lima belas tahun, atau kalau umurnya tidak nyata, bahwa belum mampu kawin, diancam dengan pidana penjara paling lama sembilan tahun.

(2) Penuntutan hanya dilakukan diatas pengaduan, kecuali jika umurnya wanita belum sampai dua belas tahun atau jika ada salah satu hal tersebut Pasal 291 dan Pasal 294. ${ }^{7}$

Menurut R.Soesilo ${ }^{8}$ ada rumusan-rumusan delik yang harus dipenuhi dalam Pasal 287 KUHP, yaitu:

a. Pelaku pelanggaran haru mengetahui atau patut dapat menyangka, bahwa perempuan yang bersangkutan belum berumur 15 tahun, jika umur itu belum nayata, bahwa perempuan ini belum masanya kawin.

\footnotetext{
${ }^{6}$ Moeljatno, KUHP, 2001, (Jakarta: Bumi Aksara), hlm 104.

${ }^{7}$ Ibid, 105.

${ }^{8}$ R,Soesilo, kitab Undang-undang Hukum Pidana (KUHP) serta komentar-komentarnya lengkap Pasal demi Pasal, 1980, (Bogor, Politeia), hlm 183.
} 


\section{Zurnal Negara dan $\mathcal{X}$ eadilan \\ p-ISSN 2302-7010 e-ISSN 2721-9801}

b. Persetubuhan iu harus betul-betul dilakukan. Jika belum dilakukan, maka perbuatan itu dapat dikenakan Pasal 190 ayat (2) yaitu, hanya perbuatan cabul.

c. Perempuan itu harus bukan istrinya, jika istrinya sendiri maka dapat dikenakan Pasal 288, akan tetapi persetubuhan itu harus berakibat luka pada tubuh perempuan tersebut.

d. Peristiwa tersebut merupakan delik aduan, kecuali jika usia perempuan tersebut belum mencapai 12 tahun, atau peristiwa

\section{Yurisprudensi} tersebut berakibat luka berat atau mati.

Putusan Mahkamah Agung Republik Indonesia No 93/K/Kr/1976 “perngadilan negeri berwenang untuk memeriksa dan memutus perbuatan yang menurut hukum adat dianggap sebagai perbuatan pidana yang mempunyai bandinganya dengan KUHP. Delik adat zina merupakan perbuatan terlarang mengenahi hubungan kelamin antara pria dengan wanita, terlepas dari tempat umum atau tidak perbuatan tersebut dilakukan seperti halnya yang ada dalam Pasal 284 KUHP ataupun terlepas dari syarat apakah salah satu pihak itu telah kawin atau tidak sepeeti dalam dimaksud dalam Pasal 284 KUHP”.

(a) Putusan Pengadilan Negeri Banda Aceh, Nomor 51/1971

1. Znb binti Mhmd, umur kira-kira 19 tahun, lahir di kampung Tanjung, Mukim Kheuh, Kecamatan Lho'nga, Kabupaten Aceh Barat; alamat, kampung Nusa, Mukim Khueh, Kabupaten Aceh Besar, Belum kawin.

2. Hsy bin Hmz, umur 26 tahun, lahir di kampung Nusa, Mukim Khueh, Kecamatan Lho'ngan, Kabupaten Aceh Besar. Alamat, Kampung Nusa, Mukim Khueh, Kabupaten Aceh Besar, Belum kawin.

Tertuduh I dan II ini melakukan zina atas dasar suka sama suka sebanyak 6 kali, sampai mengakibatkan tertuduh I hamil. Dasar hukum yang digunakan dalam pengambilan putusan dalam masalah ini adalah undang- undang darurat No 1 tahun 1951 Pasal 5 ayat (3) huruf b jo Pasal 284 KUHP.

\section{Pasal 5 ayat (3) huruf $b$}

Hukum materil sipil dan untuk sementara waktupun hukum materil pidana sipil yang sampai kini berlaku untuk kaulah-kaulah daerah swapraja dan orangorang yang dahulu diadili oleh pengadilan adat, ada untuk tetap berlaku untuk kaula-kaula dan orang itu, dengan pengertian:

- Bahwa suatu perbuatan yang menurut hukum yang hidup harus dianggap sebagai perbuatan pidana, akan tetapi tiada bandinganya dnegan Kitab Undang-undang Hukum Pidana Sipil, maka dianggap diancam dengan hukuman yang tidak lebih dari tiga bulan penjara dan/atau denda lima ratus rupiah, yaitu sebagai hukuman pengganti bila mana hukum adat yang dijatuhkan tidak diikuti oleh pihak yang terhukum dan penggantian yang dimaksud ditangkap sepadan oleh hakim dengan besar kesalahan yang terhukum, dan 


\section{Zurnal Negara dan $\mathcal{X}$ eadilan \\ p-ISSN 2302-7010 e-ISSN 2721-9801}

- Bahwa bilamana hukum adat yang dijatuhkan itu menurut fikirab hakim melampaui padanya dengan hukuman penjara dan/atau denda, yang dimaksud diatas, maka atas kesalahan terdakwa dapat dikenakan penjara dengan pengertian bahwa hukuman adat yang menurut pengertian hakim tidak selaras lagi dengan zaman senantiasa mesti diganti seperti tersebut diatas, dan

- Bahwa suatu perbuatan yang menurut hukum yang hidup harus dianggap perbuatan pidana dan yang ada bandinganya dalam Kitab Hukum Pidana Sipil, maka dianggap diancam dengan hukuman yang sama dengan bandinganya yang mirip kepada perbuatan pidana. $^{9}$

d.Keputusan Mahkamah Agung No 349/K/Kr/1980 tertanggal 26 Desember 2018 mengenai perkara Pasal 284 (1) Ia KUHP.

- Dalam undang-undang No 1 Tahun 1974 tentang Perkawinan, dianut azas monogami sebagai tertera pada Pasal 3 undang-undang tersebut dan menurut Pasal 4, Pasal 5 seorang suami hanya dapat beristri lebih dari seorang bila diizikan oleh Pengandilan Agama, sedangkan izin tersebut hanya dapat diberikan dalam keadaan dan bila dipenuhi syarat- syarat tercantum dalam Pasal-pasal ini.

- Dengan demikian terhadap para suami (yang tidak tunduk pada BW Pasal 27) yang tidak ada izin beristri lebih dari seorang, berlaku pula azas monogami seperti yang tersebut pada Pasal $27 \mathrm{BW}$.

- Maka Pasal 284 1a KUHP berlaku pula pada para suami, yang tindak tunduk pada Pasal $27 \mathrm{BW}$. Dan tidak ada izin dari Pengadilan Agama untuk beristri lebih dari satu, yang melakukan perzinaan sudah berlakuknya Undnag-undang Pokok Perkawinan.

- Oleh karena itu, seorang suami yang berzina baik hal tersebut dilakukan dengan seorang wanita yang telah maupun belum kawin, melakukan perzinaan ini sebagai "pelaku" (dader).

- Maka dalam hal ini seorang suami berzina dengan seorang wanita yang kawin, seperti halnya kasus dalam putusan mahkamah agung tersebut, ia dapat dipersalahkan sebagai "pelaku" perzinahan sebagaimana yang tersebutb dalam Pasal 284 KUHP. ${ }^{10}$

Putusan Pengadilan Negeri Sukabumi No 203/Pid.S/1978 PN.Sm. terhadap pidana Perzinaan atas nama Cecep Iskandar bin Ajun dan Nyi Aminah Mariyani Binti Obon. Keputusan Mahkamah Agung No 561 K/Pid/1982 Atas nama : Sml

\footnotetext{
${ }^{9}$ Undang-undang Darurat Nomor 1 Tahun 1951.
}

${ }^{10}$ SEMA Nomor 8 Tahun 1980. 


\section{Zurnal Negara dan $\mathcal{X}$ eadilan \\ p-ISSN 2302-7010 e-ISSN 2721-9801}

Bin H Abdr, Umur 35 Tahun dan Twh (istri Rsd) telah melakukan tindak pidana Perzinaan.

Kebijakan Formulasi Hukum Pidana dimasa yang akan datang Terhadap Tindak Pidana Perzinaan dalam Pembaharuan Hukum di Indonesia

Criminal Policy atau kebijakan hukum pidana merupakan suatu bentuk kebijakan dalam upaya penanggulangan tindak pidana yang sedang berkembang di dalam masyarakat. Kebijakan kriminal ini mempunyai tujuan Sebagai perlindungan masyarakat (social defences) dan untuk mencapai kesejahteraan masyarakat (social welfere). Kebijakan formulasi ini sebagai usaha untuk merumuskan atau menformulasikan suatu undang-undang yang dapat menanggulangi sebuah sebuah kejahatan. Tahapan formulasi ini merupakan tahap yang strategis, karena adanya kesalahan kecil didalam tahapan ini dapat berakibat fatal untuk keberlanjutan kebijakan kedepan.

Menurut Soedarto, ${ }^{11}$ pembaharuan hukum pidana harus menyeluruh yang artinya meliputi pembaharuan hukum pidana materil, hukum pidana formil, dan hukum pelaksanaan pidana. Dalam pembaharuan ini, ketiga aspek itu harus dilakukan secara bebarengan. Kebijakan formulasi yang akan datang ini merupakan pembaharuan hukum yang khusus pada hukum materil. Pembaharuan hukum ini mengandung makna sebagai upaya untuk melakukan reorientasi dan reformasi hukum pidana yangsesuai dengan nilai-nilai yang berkembang didalam masyarat. Yaitu nilai- nilai sosio politik, sosio filosofik, dan sosio kultural mayarakat indonesia yang melandasi kebijakan sosial, kebijakan kriminal, dan kebijakan hukum di Indonesia. ${ }^{12}$

Adapun rumusan kebijakan formulasi yang dilakukan untuk menanggulangi tindak pidana perzinaan di Indonesia adalah sebagai berikut:

a. Konsep RUU KUHP

Dalam RUU KUHP Versi September 2019 tindak pidana perzinaan diatur dalam Pasal 417, yaitu sebagai berikut:

Pasal 417 RUU KUHP

(1) Setiap orang yang melakukan persetubuhan dengan yang bukan suami atau istrinya dipidana karena perzinaan dengan pidana penjara paling lama 1 (satu) tahun dan denda kategori II.

(2) Tindak pidana sebagai mana dimaksud dalam ayat (1) tidak dilakukan penuntutan kecuali atas pengaduan suami, istri, orang tua, dan anak.

(3) Terhadap pengaduan sebagaimana ayat (2) tidak berlaku ketentuan sebagaimana dimaksud dalam Pasal 25, Pasal 26, dan Pasal 30.

(4) Pengaduan dapat ditarik kembali selama pemeriksaan di sidang pengadilan belum dimulai.

\section{Pasal 418 RUU KUHP}

${ }^{11}$ Sudarto, Hukum pidana dan Perkembangan Hukum Masyarakat "Kajian Terhadap Pembaharuan Hukum Pidana”, 1983, (Bandung: Sinar Baru), hlm 107.

12 Barda Nawawi Arief, Bunga Rampai Kebijakan Hukum Pidana, 2014, (Jakarta: Kencana), hlm 30-31. 


\section{Zurnal Negara dan $\mathcal{X}$ eadilan \\ p-ISSN 2302-7010 e-ISSN 2721-9801}

(1) Setiap orang yang melakukan hidup bersama sebagai suami isri diluar perkawinan dipidana dengan pidana penjara paling lama 6 (enam) bulan atau pidana denda paling banyak kategori II.

(2) Tindak pidana sebgaimana dimaksud pada ayat (1) tidak dilakukan penuntutan kecuali atas pengaduan suami, istri, orang tua dan anaknya.

(3) Pengaduan sebagaimana ayat (2) dapat juga diajukan oleh kepala desa atau dengan sebutan lainya sepanjang tidak terdapat keberatan dari suami, istri, orang tua atau anaknya.

(4) Terhadap pengaduan sebagaimana dimaksud pada ayat (2) tidak berlaku ketentuan Pasal 25, Pasal 26, dan Pasal 30.

(5) Pengaduan dapat ditarik kembali selama pemeriksaan di sidang pengadilan belum dimulai.

\section{Pasal 419}

Setiap orang yang melakukan persetubuhan dengan seseorang yang dketahuinya bahwa orang tersebut merupakan anggota keluarga sedarah dengan garis lurus atau kesamping sampai derajat ketiga dipidana dengan pidana penjara paling lama 12 (dua belas) tahun.

RUU KUHP ini telah merivisi Pasal 284 KUHP peninggalan Belanda, yang mana hanya mengancam pidana bagi pelaku perzinaan diluar nikah, jika salah satu atau keduanya telah terikat perkawinan yang sah atau tunduk pada Pasal 27 BW. Tetapi didalam RUU KUHP ini telah memperluas pemaknaan tindak pidana perzinaan. Yaitu memberikan sanksi pidana kepada pelaku perzinahan diluar nikah, siapapun pelakunya tidak ada syarat salah satu atau keduanya telah menikah atau tunduk pada Pasal $27 \mathrm{BW}$.

KUHP maupun RUU KUHP ini sama-sama mengkategorikan perzinaan sebagai delik aduan (klacktdelict). Menurut penulis, kategori delik perzinaan adalah masuk sebagai delik biasa. Karena melihat dari asas monogami yang ada didalam undang-undang perkawinan undang-undang No 1 Tahun 1974. Karena di Indonesia, pernikahan itu bukan hanya ikatan perseorangan, tetapi juga ikatan kedua keluarga. Kalau melihat hal seperti itu, maka pernikahan di Indonesia itu ranahnya sudah masuk dalam ranah publik bukan privat lagi. disini sudah menyangkut nilai-nilai masyarakat luas yaitu mencakup kepentingan keluarga, masyarakat dan lingkungan. Dengan demikian, kalau dilihat dari segi kebijakan, maka kurang bijaksana jika perzinaan ini masuk sebagai kategori delik aduan.

\section{KESIMPULAN}

Formulasi hukum pidana di masa yang akan datang terhadap tindak pidana perzinaan dalam pembaharuan hukum di Indonesia, yaitu dengan dirumuskannya Konsep RUU KUHP versi September 2019 yang telah ada beberapa perluasan tentang pemaknaan zina, yaitu: pertama, merumuskan perzinaan dalam segala bentuk, baik yang adultari (muhson), ataupun yang fornication (ghairu muhson) sebagai tindak pidana. Kedua, didalam RUU KUHP ini delik perzinaan masih dikategorikan sebagai delik aduan. Sesuai dengan undang-undang bahwa perkawinan di Indonesia itu menganut azas monogami. pernikahan dipandang sebagai suatu hal yang sakral dan suci. Bahkan pernikahan ini masuk dalam ranah 


\section{Jurnal Negara dan $\mathcal{X}$ eadilan \\ p-ISSN 2302-7010 e-ISSN 2721-9801}

publik bukan privat lagi. Pernikahan di Indonesia bukan hanya perjanjian anatar perseorangan, tetapi juga perjanjian dengan keluarga dan juga kerabat kedua belah pihak. Jadi melihat dari segi kebijakan, sebaiknya perzinaan itu masuk dalam kategori delik biasa, bukan kembali menjadi delik aduan. Ketiga, dalam RUU KUHP ini juga telah mengatur tentang kumpul kebo dan incest.

\section{Buku}

\section{DAFTAR PUSTAKA}

Adami Chazawi, Tindak Pidana Mengenai Kesopanan, Jakarta: Raja Grafindo Persada. Barda Nawawi Arief, 2014, Bunga Rampai Kebijakan Hukum Pidana, Semarang:

Kencana.

Barda Nawawi Arief, Perbandingan Hukum Pidana, Jakarta: Persada.

Eman Sulaeman, 2008, Delik Perzinaan dalam Pembaharuan Hukum Pidana Islam, Semarang: Walisongo Press.

Hanitejo, Ronny Soemitro, 1990, Metodologi Penelitian Hukum dan Jurimetri, Jakarta: Ghalia Indonesia.

Hans Kelsen, Teori Hukum Murni Dasar-dasar Hukum Normatif sebagai Ilmu Hukum Empirik.

Ismu Gunadi, Jonaedi Efendi, 2014, Cepat dan Mudah Memahami Hukum Pidana,

Jakarta: Prenadamedia Group.

Kartika Sari, "Forgiveness pada istri sebagai upaya untuk mengembalikan keutuhan rumah tangga akibat perselingkuhan suami”, jurnal psikologi UNDIP Vol.11.no1 April 2012.

Laden Marpaung, 2004, Kejahatan Terhadap Kesusilaan dan masalah prevensinya,

Jakarta: Sinar Gravika.

Musthofa Al Badawi, 2013, Zina Mengungkap Ancaman, Fakta, dan dampak buruknya,

Sukoharjo: Pustaka Arafah.

M Nur Irfan, 2014, Gratifikasi dan Kriminalitas Seksual dalam Hukum Pidana Islam,

Jakarta: Amzah.

M Yahya Harahap, 2008, Pembahasan Permasalahan dan Penerapan KUHAP Penyidikan dan Penuntutan, Jakarta: Sinar Raja Grafindo Offset.

Neng Djubaedah, 2010, Perzinaan dalam Peraturan Perundang-undangan di Indonesia ditinjau dari Hukum Islam, Jakarta: Kencana Prenada Media Group.

Peter Mahmud Mrzuki, 2005, Penelitian Hukum, Jakarta: Prenada Media.

R Susilo, 1996, KUHP Serta Komentar-komentar Lengkap Pasal demi Pasal, Bogor: Politeia.

Ridwan, 2006, Kekerasan Berbasis Gender, Purwokerto: Pusat Studi Gender,

Soerjono Soekanto, dan Srimuji, 2004, Penelitian Hukum Normatif "suatu Tujuan Singkat”, Jakarta: PT Raja Grafindo Persada.

Sudarto, 1977, Hukum dan Hukum Pidana, Bandung:Alumni. 


\section{Jurnal Negara dan Keadilan \\ p-ISSN 2302-7010 e-ISSN 2721-9801}

Wirjono Projodikoro, 1986, Asas-asas Hukum Pidana di Indonesia, Bandung: Eresco.

\section{Perundang-undangan}

Moljatno, 2001, KUHP, Jakarta: PT Bumi Aksara

Republik Indonesia, Konsep RUU KUHP Versi September 2019 Republik Indonesia, Undang-undang Darurat No 1 Tahun 1951

Republik Indonesia, Putusan Mahkamah Agung Republik Indonesia No 93/K/Kr/1976

Republik Indonesia, Keputusan Mahkamah Agung No 349/K/Kr/1980

Republik Indonesia, Keputusan Mahkamah Agung No 561/K/Kpid/1982

\section{Website/Internet}

Kartika Sari, "Forgiveness pada istri sebagai upaya untuk mengembalikan keutuhan rumah tangga akibat perselingkuhan suami", jurnal psikologi UNDIP Vol.11.no1 April 2012.

Utami Diah Kusumawati, Tercatat Anggka Aborsi Meningkat di Perkotaan, https://www.cnnindonesia.com/nasional/20141029111311-12-

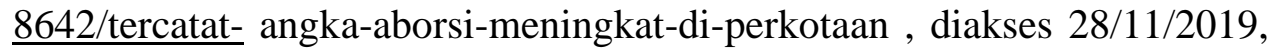
pukul 23.31 WIB. 